\title{
Dirty Hands and Clean Gloves: Liberal Ideals and Real Politics
}

\author{
Richard Bellamy, University College, London (UCL)
}

\begin{abstract}
Can liberal ideals clean up dirty politicians or politics? This article doubts they can. It disputes that a 'clean' liberal person might inhabit the dirty clothes of the real politician, or that a clean depoliticised liberal constitution can constrain real world dirty politics. Nevertheless, the need for a democratic Prince to wear clean liberal gloves offers a necessary and effective political restraint. However, it also means that citizens share the hypocrisy and dirt of those who serve them - for we legitimise the dirtiness of politics by requiring politicians to seem cleaner than we know they ever can be in reality.
\end{abstract}

Key Words: Democratic politics, dirty hands, legitimacy, public, private, Machiavelli, Rawls, Weber

With a few notable exceptions, politicians - even democratic politicians, who form the subject of this article - do not enjoy a good press, either among philosophers or the wider public. Cynicism provides the default position of most citizens in most of the world's democracies. As Michael Walzer famously remarked, it is the 'conventional wisdom' (that is, 'the wisdom of the rest of us') 'that politicians are a good deal worse, morally worse, than the rest of us'. ${ }^{1}$ That common attitude can seem justified not just by the expenses and sex scandals that periodically hit the headlines, or even the backbiting and backstabbing that attends most ascents up the greasy pole of politics, but also by the need for democratic politicians to make deals and compromises either to accommodate diverse groups and interests and build coalitions between them, or to square the different and often conflicting moral concerns and considerations present within hard cases and difficult decisions. Both the 
personal and the political compromises can make politicians appear untrustworthy, unprincipled, and occasionally ruthless, hypocrites. Indeed, the tendency for the media to concentrate on the personal improprieties of politicians as much as - in certain cases, even more than - their public wrongdoing, can make it seem that the two are all of a piece. On this account, either politics is dirty because those involved in it are, or it is a dirty business that appeals to dodgy characters. Cleaning up political life, therefore, depends on either attracting a cleaner sort of person into politics or depoliticising it as much as possible. This article disputes both these views. Popular though these prescriptions are, neither seems to go to the heart of the ethical problems surrounding public life.

There is little evidence that the personal morality of the average democratic politician is worse than that of the average citizen. Politicians simply operate under the public gaze and for the public good, so we know more about them and expect more of them. After all, the incentives and opportunities of many private individuals to commit minor crimes and misdemeanours can be as great if not greater than that of the general run of politicians. Their doing so can even be as well known. But they rarely attract the same intensity or quality of opprobrium. Within most working democracies, the financial gains to be made by fair means or foul from politics are less than those available in business, while sports stars, actors and musicians frequently enjoy greater social prestige and celebrity than politicians. The corresponding economic and socio-cultural power exercised by these groups offer if anything more potent occasions than political power for either fraud and deception or vain glorious behaviour and sexual impropriety. Yet the few who succumb to these temptations are as likely to attract envy or amusement as censure. Indeed, polls indicate that a high percentage of the general population indulge in mild sexual and personal transgressions - be it cheating on taxes or on their wives and husbands - with far less inducement. We know these facts 
about ourselves yet desire better of those that represent us because we expect them to serve our interests rather than their own.

Do such double standards make not politicians but us ordinary citizens the hypocrites? Or does politics require we hold politicians to a higher standard of moral judgement to that we would apply to ourselves? Most people do not have to read Adam Smith to appreciate that supermarkets, trades people and all the other businesses and services we draw on to supply our material wants do so not from an altruistic desire to meet our needs but in order to make a profit and serve their own. ${ }^{2}$ Nevertheless, we shrink from accepting that politicians might be similarly motivated. In part, we do so for the good reason that markets and other social activities are not entirely self-policing, nor would we be entirely happy with them being so. So we look to politicians and other public servants to aim conscientiously at upholding the public good, not least by regulating the activities of those - including ourselves - who might be tempted to subvert it. However, this very desire contains a paradox. For the standard required of politicians proves to be a different rather than simply a higher criterion to that expected of private individuals - one that from the perspective of the citizen may well make politicians appear worse rather than better than the rest of us. Yet, that appearance may be illusory if, as often is the case, private virtue turns out to be public vice.

Public decisions differ from private ones in numerous respects. ${ }^{3}$ They entail higher stakes, involve more people, frequently deal with weightier matters, and typically involve coercive means for their enforcement. As a result, there is more likelihood that some people will lose that the greater good may prevail, that a poor or unlucky decision will have severe consequences, that states and their agents may need to do things that private individuals ought not to do, such as using falsehoods and violence, and that a degree of hard headedness may be required to confront a difficult decision - be it a financial crisis or a military threat. 
Therefore, in serving the public interest it will be hard for the politician either to act in the same way as a good private person might be expected to do, or to be responsive to all our private interests. So politicians will gain 'dirty hands' in part because those they serve (the rest of us) make conflicting and exacting demands of them. For the sake of the common welfare, they may be forced to renege on their supporters or win people over through flattery, bribes or threats, and to commit acts which we would normally strongly disapprove of. To secure the good, they may have to sacrifice the best. In so doing, they may need to acquire a certain cunning and callousness. Thus, we expect politicians to be better than the rest of us in pursuing the public rather than their personal good. Yet, because the public good is so hard to realise - not least because we ourselves are less than perfect, or simply have different and occasionally conflicting views of what it entails - they will be compelled to behave worse than the rest of us and dirty their hands.. Hence the difficulty: we desire principled politicians but expect - even oblige - them to commit unprincipled acts.

Some seek to get round this difficulty by conceiving the principles governing the behaviour of politicians not as general moral principles, applying equally to private and public life, but as sui generis principles of political morality. ${ }^{4}$ These principles supposedly reflect public reasons that all reasonable affected political actors, be they citizens or ministers, would be able to accept - or at least not reject - because they treat them with equal concern and respect in their capacity as reasoning agents who seek to pursue a variety of different conceptions of the good within the same public space. The most ambitious schemes seek to ground public policy on such reasons. ${ }^{5}$ The less ambitious see such reasons as simply defining the ground rules governing the necessary public interactions of free and equal citizens. ${ }^{6}$ As such, they offer side constraints on how any policy could be made or what its content might be. Either way, the aim is to ensure the politician can act only in ways that 
might be defended in the light of such public reasoning. The implication is that what could not be so justified would be unjustifiable. So constrained, the scope for politicians to practice the dark arts of politics will be suitably delimited.

However, this proposal succumbs to the further difficulty that the very aspects of political life that differentiate public from private morality also undermine the possibility of the consensual norms of public reason on which this thesis rests. The features of the public sphere adverted to above as dirtying the hands of politicians can be related to what have been called the 'circumstances of politics'. ${ }^{7}$ These circumstances reflect a situation where we need a collectively binding agreement backed by state power, because our lives will suffer without it, yet opinions and interests diverge as to what its character should be and no single demonstrably best solution is available. Politicians have to operate not with the public reasons of ideally reasonable agents, but the real reasons of the public which tend to reflect competing concerns and complex situations. ${ }^{8}$ Along with considerable empirical uncertainty as to the causes of any problem and the likely consequences of different solutions to it, there will be normative disagreements - some of them related to these empirical questions, others not - as to which policies best promote, or are compatible with, equal concern and respect and ought to be collectively pursued As a result, a key task confronting any politician is the reconciliation of incompatible values reflecting distinct forms of social and moral reasoning. Yet, unlike natural science, there is no agreed epistemology or method for selecting between these views other than the process of politics itself. Conservatives, Liberals and Socialists, Utilitarians, Kantians, Aristotelians and Nietzscheans, largely operate with different and incommensurable justifications for their core beliefs that lead them to focus on different features of a given policy and look to different sets of public reasoning to support their views. There is no entirely 'public' way of resolving such disputes, no Archimedean position that unequivocally pays equal concern and respect to all relevant, reasonable views in an 
uncontentious way. Even a procedural device, such as voting, will be subject to these sorts of disagreements, such as those relating to the fairness and appropriateness of different voting procedures. Confronted with these plural and competing demands of citizens, it will be necessary for the politician to juggle with different and occasionally incompatible kinds of public reason and attempt to mould them into the semblance of a coherent policy. Public reasoning thereby enters the realm of dirty politics. Politicians will be obliged to employ less than full candour, using ambiguity and a certain flexibility in their own principles to address the various competing constituencies among the public whom they must serve. Frequently, they will find it necessary to practice a degree of double-dealing, making incompatible promises to different groups to square the circle of irreconcilable interests and views, all possessing a degree of legitimacy. Meanwhile, and for related reasons, they will be fated to do violence to certain values and possibly forced to covertly employ the coercive power of the law to bring at least some of those who disagree into line. As we shall see, the claim that a definitive set of public reasons or form of public reasoning could constrain politics and cleanse it so as to remove such political sleights of hand from collective decision-making involves a denial of the pluralism of liberal societies and the diversity of pressures it generates.

As sections one and two aim to show respectively, these difficulties bedevilling both a basic 'human' and a 'public' morality undermine the prospects of having either a 'clean' person behind the dirty politician or a ‘clean’ politics constraining the politician's dirtiness. Both possibilities have appealed to liberal idealists and to the rhetoric of rights. The first lies behind the view of human rights as establishing universal duties to 'humans as such'. ${ }^{9}$ This proposal overlooks how the very source of the dilemma stems from politicians having duties related to their political role that cannot be read from or linked to whatever duties they may 
have simply as persons- a notion that is itself hard to conceive of. The second lies behind notions of constitutional rights as establishing the basis of a political system and thereby sanitising politics by in certain respects 'depoliticising' it. ${ }^{10}$ However, these schemes ignore how such rights are themselves within the 'circumstances of politics', raising the self-same dilemmas they are supposed to dissolve or control. Section three then looks at the realist tradition of Machiavelli as updated for the democratic Princes of present day liberal democracies by Max Weber. ${ }^{11}$ On this account, politicians may need to act dirty, but they must appear clean - not least because we expect them to be so, even if we know they cannot be. Ultimately, the source of public reasons is the public themselves, and the limits of the legitimate use of force and guile are what citizens judge proportionate to the task at hand. Here, hypocrisy on both sides has what Elster, in another context, refers to as a 'civilizing effect'. ${ }^{12}$ Seeming good even while having to learn to be bad offers the best we can hope for. Politics is inevitably dirty, but public acceptability obliges politicians to wear clean gloves and only employ those means required to achieve ends that serve public interests - or face the electoral penalty for failure. ${ }^{13}$ In which case, political theory does indeed need to get real, though remaining clothed in a degree of liberal idealism.

\section{Clean Persons: Can Politicians Wash Their Dirty Hands by Being Good Individuals?}

It is tempting to believe that politics would be a great deal better if only good men and women could be attracted into it. Yet the advocates of both liberal idealism and political realism believe public/political ethics cannot be derived from personal morality, though they give very different accounts of what such a distinctive political morality entails. Indeed, in different ways both consider that in certain crucial respects the good person is likely to be a bad politician. ${ }^{14}$ On the one hand, a public official may have moral obligations that are not 
only different to but conflict with those that he or she may have as a private individual. On the other hand, those public moral obligations may be not only non-derivable but also detached from personal moral obligations. For, there may be no general moral obligations that we have simply as persons which serve as their common core. ${ }^{15}$

Both these views, but especially the second, are controversial. For example, Martin Hollis quotes Thomas Jefferson as denying both by remarking (in a letter of 1809) that 'I never did or countenanced, in public life, a single act inconsistent with the strictest good faith; having never believed there was one code of morality for a public and another for a private man'. ${ }^{16}$ Jefferson's position certainly resonates with many of the more popular critiques of politicians. Yet, in its simplest version at any rate, it seems simplistic. For a start, most people acknowledge we have moral duties in the private sphere - to family and friends, for example - that would be inappropriate to carry over to the public arena. Nepotism may be allowable, even a parental obligation, with regard to the family firm, but we rightly question it in the case of elected public office. In the circumstances of a sinking ship, most of us would think it a mother's duty to prioritise getting her children into the lifeboats. Yet, if she is the Captain it would be a dereliction of her professional obligations not to prioritise keeping the ship afloat for as long as possible and an abuse of her position to treat her own children any differently to other passengers. ${ }^{17}$

Consistent moralists who stick rigidly to the clear cut moral dictates of their conscience come what may, treating both private and public alike, seem similarly inept. Theirs is the attitude of the saint, willingly embracing martyrdom rather than sacrifice principle to expediency. That can seem appealing - we rightly admire the moral courage of one who refuses to accept he could ever have a moral duty to be a concentration camp guard and send Jewish children to the gas chambers. Yet, neither liberal idealists nor political 
realists have regarded saints as suited to public life. The former fear their intolerance, the latter their ineffectiveness. Going to the stake for your beliefs may be admirable in its way, but for their different, if related, reasons Rawlseans and Machiavellians agree that one should not expect to take others with you. Saints concede nothing either to those who hold different moral views to theirs, or to the failure of the world to measure up to their expectations of it. Personal salvation, be it in the hereafter or in their own estimate of themselves, permits them either to keep their own hands clean but at the expense of leaving the rest of us in a dirty situation, or to attempt to clean up us and the rest of the world whatever the dirtiness of the cost. In both cases, heaven is purchased at a terrifying price - be it of allowing the rest of us to go to hell or of creating a hell on earth to save us all.

As Sue Mendus has noted, ${ }^{18}$ the position of the saint - what Weber called 'the ethics of conviction' - reveals a potential tension between personal integrity and impartiality, be it through showing the views of others equal concern and respect, or by attending to the consequences of our actions for the greater good. Pluralism, either of views or interests, is treated as error, while what Weber called 'the ethical irrationality' of the world, whereby good - or well-intentioned - acts may give rise to bad results, a sign of its wickedness. Saints keep their hands clean, but by ignoring the concerns of others and the need to treat them on a par with their own - what Weber called 'the ethic of responsibility'. Given that we expect politicians to act for the public good - even if in so doing they go against their own interests or beliefs - then preserving the moral integrity of a saint in public life seems not just irresponsible but even immoral. ${ }^{19}$

A more sophisticated version of personal moral integrity, though, might allow conviction to be balanced by responsibility. The saint or a humanist moral absolutist might do the right thing not to achieve personal salvation - a sort of moral self-interest - but because it 
is the right thing. ${ }^{20}$ Moreover, in a case where doing the right thing would have clear and terrible consequences for many others, then a broader notion of keeping faith with one's principles suggests the right thing might be to modify that absolutist position, albeit with the proviso that certain measures would be impermissible whatever the consequences. ${ }^{21}$ Murder is wrong but, in the context of a just war against a determined and brutal regime bent on mass genocide, a pacifist position may not be right even to one strongly committed to the injunction 'Thou shalt not kill'. True, as a soldier one will almost certainly risk killing not only evil enemies but also innocent non-combatants and enemy soldiers who have hitherto lived blameless lives yet felt - possibly for reasons that are themselves far from morally clean cut, such as fear for their families if they did so, or simply a lack of personal courage - unable to resist being called up by a tyrannical and cruel regime they had never previously supported. However, doctrines such as double-effect and proportionality exist to determine what the moral soldier may do even in a just cause brought about by the sort of special circumstances required to modify the absolutist position. In this sophisticated picture, it is still the moral individual who stands behind the soldier and sets constraints on what even a soldier might do. ${ }^{22}$ As a result, the good soldier retains clean hands, or at least the good person behind the soldier does. Much the same applies to a politician who finds him or herself having to declare and then conduct a war against an aggressive and oppressive regime. Developing this line of reasoning leads Walzer to suggest that politicians (or soldiers) only realise they have dirty hands to the extent they are also good persons. ${ }^{23}$ Paradoxically, on this account, we should only feel happy with the dirty politician who is at bottom clean.

This sophisticated position turns on abstracting to a universal moral code behind any special circumstances, and to a universal moral individual behind any social role. ${ }^{24}$ However, it is not obvious either abstraction is possible. As Martin Hollis has noted, we encounter 
moral dilemmas as social actors within social situations and relationships that are in part framed by the beliefs we hold about our respective entitlements and obligations and the likely consequences of our actions and interactions. ${ }^{25}$ Thus, what makes the soldier a good soldier is not that he is also a good man who follows a universal code but that he is a soldier who follows the moral code of soldiers. That moral code is not simply a universal code modified to take into account the special moral circumstances of being a soldier. This becomes clear when as a soldier he finds himself caught between roles such as the overlapping duties of comradeship and friendship. Suppose to help a fallen friend he would have to put at risk other comrades to whom he had no such tie. His situation here would be like the Captain and the mother in the earlier example. But what makes this a dilemma is that there is no point beyond the two roles to which he could retreat to ask what is universally required. It makes no sense here to ask 'what is the duty of the good man to other men?' - the duties are those of soldier and friend. Nor is there a place above the conflict where one might seek to adjudicate between these two roles. The difficulties arise from the duties of the good friend and the good soldier being different, though not so clear cut that they do not become entangled in that a comrade is like and can be a friend, with only circumstances perhaps defining what should take precedence though a moral loss exists whatever the decision. In these situations, neither the responsibility of Captain or mother, soldier or friend can be shaken off to reveal the merely human, universal moral issue underlying them both. These roles and the beliefs we hold about them frame the situation, and there is no situation to address without them.

This position may appear too relativistic, making us creatures of the roles and the conventions that surround us at a given time and place. In this case, then surely the 'good Nazi' would merely be doing his duty and acting with impunity in following the orders that sent millions to the gas chambers? I agree certain orders should not be obeyed, but I do not 
accept one has to go back to the 'good' person and the universal moral code to justify doing so. Although the contemporary rhetoric of universal human rights might seem to evoke such an argument to tackle these sorts of situation, the deliberations of international rights courts tend to be more guarded because matters rarely present themselves in very straightforward terms. Indeed, as we have seen, no purely human and simple moral context proves available to us. Take the case of the good German professional soldier who finds himself suddenly employed by the Nazis. It might be argued he could desert and refuse to fight for such an odious regime. Yet he might equally consider that his duty as a good German soldier lay in seeking to save as many people from the 'good Nazi' as he could. The choice here, though, is not between that of a good man and that of a good soldier, for either way the moral responsibility of what his office requires remains. That office as plausibly indicates that he should soldier on as that he should resign, with the putative moral duties of the good man as such offering no guide at all as to which choice he should make. Whatever the choice, he cannot wash his hands or keep them clean. So attempting to ask what the 'good man' should do offers no help - it is too abstracted from the actual situation in which he finds himself $-\mathrm{a}$ situation at least partly shaped by prevailing social beliefs about his role and circumstances. Doing the right thing here involves doing what is right - or at least morally defensible -given the social relations and beliefs that create the moral dilemma in the first place - not doing what was right regardless of this social context or what he simply thought was right.

What makes the politician a morally good politician, therefore, does not rest on his or her being a good person, or even necessarily a good husband or wife, father or mother, friend or comrade and so on. At certain points, politicians may need to sacrifice family to career, drop friends and disappoint supporters to achieve or exercise power, compromise their goals and principles to gather support or accommodate others, and authorise uses of violence that 
would be regarded as wrong in a private individual. They make such decisions not as persons but as politicians, moved by a political responsibility and logic to secure a public good that inevitably involves making difficult choices between rival moral claims. These choices may result from the need to accommodate the conflicting demands of citizens - for example, when balancing budgets between education, health, transport and so on, or when contemplating how far to appease a potentially bellicose state, or in order to build a coalition of support sufficient to push through a favoured policy, sacrificing others in the process, or to form a government. In all these situations, the politician's political role will require he or she do certain things that as a private citizen or ordinary party member they either would never be in a position to do or would rather not do. Yet, even if there is no direct appeal to be made to universal moral norms of a pre-political nature, the dictates of politics need not be amoral, let alone downright immoral. A code of political ethics might still exist that the good democratic politician could draw on, even if that is not the code of the good man. It is to the form such a code might take that I now turn.

\section{Clean Politics: Can Dirty Politics be Sanitised by Good Public Reasoning?}

In recent years, liberal idealists have seen the entrenchment of rights in written constitutions and judicial review by constitutional courts as suitable mechanisms for keeping politics clean. Rights enshrine ideal liberal political principles, while courts offer a suitably depoliticised mechanism for upholding them in an impartial way. Needless to say, numerous versions of this thesis exist. I concentrate on one of them - John Rawls's Political Liberalism. Not only are most of the recent attempts to devise such schemes by liberal theorists post-Rawlsean in inspiration, but the aspiration of Rawls's theory to be 'political not metaphysical' appears to 
dovetail with the conclusion of the last section that suggests any workable theory of political morality must draw on the resources of politics itself.

Rawls seeks to achieve this result by restricting the application of the theory to the basic structure of society, excluding comprehensive conceptions of the good, and elaborating it on the basis of the principles he regards as intrinsic to a democratic public culture. ${ }^{26}$ However, despite the putatively political scope and sources of Rawls's theory, the resulting account of political justice turns out to be surprisingly apolitical - as do those of other liberal idealists. For the aim is to constrain politics morally by identifying a core set of political liberties and depoliticising all decision-making that touches on them. Rawls argues the terms of a just politics need to be given special constitutional status so as 'to fix, once and for all, the content of certain political basic rights and duties, and to assign them special priority.' 27 Doing so, he claims, not only 'takes those guarantees off the political agenda and puts them beyond the calculus of social interests, thereby establishing clearly and firmly the rules of political contest', ${ }^{28}$ it also 'removes from the political agenda the most divisive issues, serious contention about which must undermine the bases of social cooperation.' 29

The basic political liberties identified by Rawls's theory supposedly secure the moral basis for a democratic society - one in which citizens treat each other fairly and equitably when making collective decisions. As such, they supply the set of legitimate public reasons that must be respected by politicians and other public servants when pursuing the public good - especially any requirements they may place upon their fellow citizens to achieve these public ends. In Rawls's account, these reasons circumscribe both the perimeters of the public sphere (they define the 'scope' of public reasoning - namely the fundamental principles of political justice that establish a working democratic system) and the type of arguments we might muster when seeking to alter it (they provide the 'content' of public reasoning). In 
arguing that no public policy must be allowed to conflict with these principles, Rawls seeks to ensure all democratic decisions are consistent with the maintenance and improvement of a basic democratic political structure that upholds the equal rights of all citizens. On this account, therefore, decisions that respect the constitution will be clean as to both process and result. $^{30}$

Rawls does not rule out consequentialist or other types of moral reasoning that might touch on areas other than the basic political liberties. He merely argues that such policies should be consistent with them. For example, he suggests tax and environmental legislation, funding for the arts, and - one imagines - many trade and foreign policy decisions, including the conduct of wars - might all be decided on grounds that do not explicitly invoke principles of basic political justice. ${ }^{31}$ However, he contends the conduct of these policies must not infringe these principles, thereby keeping the political system itself fair and free. Rawls conceives public reasons as constitutional constraints. Because their judgments must be entirely couched in terms of constitutional law, constitutional courts provide the exemplars of such public reasoning and can legitimately strike down legislation they deem infringes the constitution. ${ }^{32}$ Thus, on Rawls account entry into a war and its subsequent prosecution might be justified in terms other than political justice but if a government thought it entailed policies that restricted basic political liberties, like Official Secrets Legislation, then such measures would need to be justified in terms of the fundamental political principles themselves and made consistent with them.

As was noted above, the difficulty with this position is that such public reasons cannot define the political sphere because they are at issue within politics. Rawls acknowledged that what he called the 'burdens of judgement' - factors similar to those we have associated with the 'circumstances of politics' - make 'reasonable disagreements' likely about which policies 
are in the public good. ${ }^{33}$ However, he thought a consensus possible on the nature of the 'right', at least for politics. The difficulty is that most policy debates about the good involve parallel and equally reasonable disagreements about the right - the two are intertwined. Meanwhile, these differences about the good and the right will impact in their turn on how the political sphere gets defined. So debates between free marketers and social democrats over how far and when the state should intervene in economic affairs not only involve different views of which policies are best for promoting economic growth or different notions of the economic good but also different views about the right and what treating people equally involves - for example, whether it requires merely that the rules are the same and respect peoples choices or necessitates a less formal and more substantive equalising of positions. The same has proven true of feminists challenging certain notions of privacy or religious or other groups seeking recognition of their cultural differences. In each case, a given conception of political justice does not frame but is at issue in the political debate.

Two problems pertinent to the present argument follow from this situation. First, to constrain political debate by constitutionalising a given view of the limits of political permissibility may itself encourage hypocrisy on the part of political actors. The entrenchment of a Bill of Rights that are subject to protection by a constitutional court does not overcome political disagreement. Be it substantive issues such as abortion and affirmative action, or procedural ones such as campaign finance and proportional representation, political debate merely moves to the judicial sphere, be it through political pressures of various kinds on the relevant courts or within the judicial decision-making process itself. Yet, instead of the full range of public reasons motivating a given issue being considered, the focus will be on how far it meets a supposed canonical reading of a given constitutional norm, thereby foreclosing proper debate. Think of how debates about the death penalty in the USA have 
become focussed on whether it is 'cruel and unusual', or the way discussion of public health warnings on tobacco in Canada became centred on whether they infringed freedom of speech. ${ }^{34}$ In this way, insistence on the best sort of public reason becomes the enemy of the public good. Instead of seeking an accommodation between the many public reasons and their various weights that standardly define a measure as one the public will recognise as being in its interest, energy is diverted into making a policy appear to be in accordance or not with a single kind of trumping public reason that may be marginal in the balance of reasons that recommend the policy in the first place. Cleaning up politics in this way just shifts the dirt into the judicial arena and risks injecting an obfuscatory moral rhetoric of 'fundamental' rights into democratic political debate that may divert attention from values and concerns that are more central to the issue at hand and might even be more politically tractable because more amenable to compromise. ${ }^{35}$

It has been suggested that some issues, such as abortion in the United States, are so divisive that it would be less disruptive to have them decided by judges, or that other issues, such as electoral boundaries, involve perverse incentives for politicians that judges do not share. However, the degree to which judicial decision-making does indeed prove more impartial than political decision-making on these matters will be largely an empirical matter, and itself partly dependent on the view point of the investigator as to what the 'best' outcome would be. Nevertheless, the claim that is often made in such cases that judges decide via a depoliticised and somehow pure reading of 'the law' can be regarded as itself a form of political deceit. It serves as a Platonic 'noble lie' - potentially useful, but itself a part of dirty politics. After all, judges differ in their forms of legal reasoning as much as citizens and politicians differ in their political reasoning. They may be originalists, textualists, natural lawyers, positivists and so on, while demonstrating a similar range of moral and ideological 
opinion as is found in the public at large. Indeed, multimember courts are for this reason often forced to compromise in a not dissimilar way to politicians and to reach decisions through 'incompletely theorised agreements'. ${ }^{36}$

The ways judicial decision-making either renders politics murkier or mirrors its murkiness relates to the second problem: the need in various circumstances for public reasons to be massaged or hidden - in part or totally - for the public interest. Massaging becomes necessary if, as tends to be the case in many political disputes, there are a number of reasonable views as to the weighting and applicability of different types of moral consideration and of how these relate to the available empirical evidence, each of which can lay claim to a certain legitimacy, so that the integrity of the politician lies in seeking to reconcile these competing claims. Seen starkly from each of these positions, that may make him or her seem to have no integrity at all. Yet, this circumstance seems a consequence of a pluralist society in which we attempt to treat all positions with equal concern and respect. For example, Aneurin Bevan burdened the National Health Service (NHS) with the goal 'to universalise the best' However, that oft-repeated aspiration is a contradiction in terms. Governments cannot avoid experimenting with various ways whereby they can give different groups of people some of what they want and arrange trade-offs between various sorts of health care. None of these policies can be regarded as a 'universal best' and so are open to never ending criticism no matter how much funding is poured into the service. Still, many such policies may claim to be reasonable attempts to achieve the public good. Unfortunately, though, expectations of the NHS make the realistic policy of 'a good enough' health service less politically defensible than the impossibly idealistic 'universal best' to which politicians are forced to commit. The only way to overcome this dilemma is to promise all groups that their needs will be met while finding surreptitious ways for meeting some more than others. 
Such massaging points to a more general problem that prevents politicians ever being entirely candid. The reasonable differences people have about the different normative and empirical reasons behind any policy mean that there will be a built in tension between politicians and their supporters. As with judicial majorities on a multimember court, the coalition of voters backing a given party will support it for reasons that the politicians must keep deliberately 'incompletely theorised'. No politician can fully articulate his or her reasons for a course of action for fear of alienating those with whom they disagree in respect of the full reasoning. The use of non-public rhetoric that worried Rawls is not just to reinforce public reasoning by appealing to deeper convictions, as he conceded might be necessary, ${ }^{37}$ but also partly because there are no genuinely public reasons to which appeal might be made. A degree of smoke and mirrors is often necessary even when presenting policies that a majority support because citizens value them not for the same reasons but for a variety of different and possibly inconsistent reasons.

In some cases, the public interest may actually require a certain economy with the truth, or for the truth to be hidden altogether. It is often claimed that credible commitments require that diplomatic negotiations be carried out in public. 'Open covenants of peace, openly arrived at' offer the only secure road to peace. Yet, such openness may make it hard for politicians to make the concessions that are necessary to an agreement without losing face before their domestic audiences. Thus, Henry Kissinger and President Nixon chose to avoid the confrontational approach that marked the 1962 Cuban missile crisis when seeking to resolve the Cienfegos Submarine Base Crisis eight years later by using secret diplomacy precisely to avoid a similar escalation by 'giving the USSR an opportunity to withdraw without humiliation. ${ }^{38}$ Likewise, the British government consistently denied negotiating with the IRA throughout the troubles so as not to offend Protestant opinion in Northern Ireland, 
while actually doing so in order to bring an end to violence and promote the peace process. As Prime Minister, John Major reportedly informed MPs the idea of talking to the terrorists 'would turn my stomach' while doing just that. ${ }^{39}$ In this case, most people would regard the lie as justified. Yet, that justification is largely ex post facto and in defiance of a public reason that would hold a government to a rigid policy of openness and publicity.

None of this is to suggest that many good policies cannot be successfully prosecuted openly and in accordance with prevailing views of constitutional essentials, or that bad policies have been pursued covertly to avoid being rightly blocked for infringing such norms. But within much normal politics the public good can be subverted by either seeking the best as defined by one criterion of a public reason, or insisting all reasons be public. Compromise between plural demands and white or dark lies may all require political reasoning be less than public and make equivocation and deceit a virtue.

\section{Clean Gloves: Real Politics and Liberal Ideals}

Do the failures of liberal idealism to get to grips with the ethical dilemmas of real politics mean there are no valid moral constraints on politics - that anything goes, as realists are sometimes portrayed as affirming? The Machiavellian political realism I wish to defend does not go that far. Machiavelli famously argued that politicians must 'learn how not to be good', but went on 'and to know when it is and when it is not necessary to use this knowledge. ${ }^{40}$ The reason rulers cannot always display all the good qualities of a virtuous person are because "we do not live in an ideal world. ${ }^{41}$ As I noted in the first section, private and public virtue often fail to coincide, with certain ways of behaving that 'seem virtuous' leading to political ruin, and others that 'are supposed to be wicked' producing political success. ${ }^{42}$ 
Machiavelli observes how this dilemma arises because Princes must engage with a world in which there are wolves and traps, and so must be willing to act as lions and employ force to overcome the one and be as cunning as foxes to avoid the second. ${ }^{43}$ Here, then, we have the two aspects of real politics that liberal idealists tend to ignore - the uses of violence, on the one hand, and the need for dissimulation, on the other. Yet, throughout his analysis Machiavelli (and following him, Weber) offers two politically motivated reasons for restraint. The first is a loose notion of proportionality - that princes should be 'bad' to the extent necessary to deal with wolves and traps and no further. ${ }^{44}$ The second is the importance of appearing all the while to be good. In each case the need for such limits is the same: politics may employ force and guile but neither can substitute for some degree of willing consent on the part of the ruled - a requirement that is all the more important in a democracy. Thus, a democratic Prince may have dirty hands, but must wear clean gloves.

One can reframe this point in the terms we have employed in the preceding analysis. Both the need for force and guile and their limits flow from the difference between the private and public spheres, and the peculiar 'circumstances of politics' that structure the latter and call for a distinctively political response. Because public policies involve collective action in the face of disagreement as to who should cooperate, how, when, to do what and where, some mix of coercion and persuasion to bring us into line becomes unavoidable. Yet, since you can neither compel nor fool all the people all the time, a degree of trust that one is a good politician - if not necessarily a good person - becomes necessary. An appeal to liberal idealism may offer the real politician these necessary trappings of legitimacy. However, as we have seen, politicians cannot really hold to these ideals consistently. It is merely politically helpful that people believe they do their best to do so. 
To put some flesh on this argument, let us explore each of the Machiavellian constraints in turn with regard to the use of violence and dissimulation respectively. The prime Machiavellian lesson concerns the need to remove all political rivals and their armed supporters from the scene, often with the use of extreme force. That offers a timely reminder of how necessary the 'monopoly of violence' is for regular government and how difficult it has been to achieve. ${ }^{45}$ Even if the elected politicians of established democracies inherit this position, and so are spared the Machiavellian blood bath, liberal idealists are apt to forget that behind the law lies coercion, so that every political decision necessarily implies the use and, in foreign affairs especially, the protection of the monopoly of force. Citizens will only value the law if it has de facto as well as de jure authority, and the state has the ability to enforce it.

As the problems besetting weak states reveal, the de facto authority of a brutal regime can have a value in itself even in the absence of any de jure legitimacy of either a formal or substantive kind - think of the problems besetting Iraq following the removal of Saddam Hussein. Yet, if the establishment of a monopoly of violence requires brutal measures, there is a difference between 'cruelty well used and cruelty abused'. ${ }^{46}$ A prince who is simply cruel not only lacks 'glory' but also is unlikely to remain in power. Force alone will never allow for stable rule, and Machiavelli `would criticise anyone who, relying on his fortresses, thought it unimportant that his people hated him. ${ }^{47}$ Certain ends may justify quite ruthless means, but that does not involve any failure to acknowledge the moral price of those means. As he notes, 'while the act accuses, the result excuses' - the deontological accusation remains notwithstanding the consequentialist justification. ${ }^{48}$ Therefore, a prince avoids abusing cruelty by staying aware of its cost in terms of both lost popularity and reputation, and the damage to different moral values that it entails. Yet, neither can ever be clearly and 
unambiguously measured. Governing is an art not a science, and success as a 'good' politician requires not only virtú but also fortuna.

It might be thought that if force is used only to the extent necessary to overcome 'wolves', then many of the dilemmas of 'dirty hands' disappear. We ought to be able to handle them within the constraints of liberal democratic values, prosecuting evil doers via a due process. Sadly, matters are not so easy. For a start, wolves also lay traps and may need to be dealt with in cunning ways. Legitimate force often rests on covert violence, and all liberal democratic governments employ professional foxes to do their dirty work. Moreover, citizens know they do, and that there are limits to how far secret services could operate publically without destroying their point. So we tolerate wire tapping of terrorists and spying on unfriendly powers, but prefer not to be told. To a degree, we share the dirt with politicians. Nevertheless, political legitimacy, measured by the tolerance of citizens for the government's dirty tricks, depends on both parties keeping faith with ideal liberal democratic forms and norms even while selectively disregarding them. If experience shows politicians to have acted disproportionally or failed, that hypocrisy allows citizens to desert them and claim the moral high ground. So politicians have good reason to be cautious. But, to repeat, such caution can never be an exact science - many politicians will find the road to hell is paved with good intentions. After all, as Machiavelli remarks - many have tempered their initial cruelty only to find they need to be all the crueller as a result. ${ }^{49}$

Meanwhile, the use of force and guile extends beyond the spilling of blood, and citizens may also be wolves to a degree. If a motorway is built through a site of natural beauty or slum housing cleared, then violence is done to certain values and the lives and livelihoods of particular people. The princely claim - hypocritical or sincerely believed - will be that it was done for the public good. To avoid costly protests and planning blight, the 
decision may even be made in secret, with the bulldozers moving in overnight. After all, many citizens will act wolfishly and with cunning to thwart such plans. Even in a mature liberal democracy, much politics happens at its borders - not least as a way of trying to extend its constitutional boundaries. Like Princes, these citizens will likewise only know if they have judged the degree of force correctly if history proves them justified. They too will need their share of virtú and fortuna.

Finally, guile and the threat - if not necessarily the use - of force prove ever necessary because politics remains a messy business in which politicians must reconcile the claims of conflicting groups. What binds these together is not a common adherence to public norms of reason, which above I doubted possible, but ambiguity and a certain economy with the truth. The plurality of concerns and values involved in any collective decision means that politics involves compromise. According to the groups involved and the issue being decided, a mutual accommodation between sufficient people to get a working majority for a given outcome may require that those involved trim their demands, split the difference, arrange a trade-off, or go for a shared second-best. ${ }^{50}$ In each of these scenarios their preferred best option gets sacrificed to the common good. Arranging such agreements may often depend on the reconciliation of incompatible demands through a sleight of hand whereby each party believes they are getting more than they actually are. For example, Michael Freeden has plausibly argued that the British post-war political consensus of the 1950s surrounding a welfare state and a mixed economy largely depended on Labour and Conservative supporters and politicians emphasising different elements of the package and giving it divergent and logically contradictory readings. ${ }^{51}$ The stability of this settlement largely depended on not making these differences too obvious. 
Thus, democratic Princes no less than the Machiavellian prince must appear compassionate, generous, reliable, morally upright and honest, yet be prepared to be treacherous, break their promises and use their resources selectively. The key is that nobody must know - or want to know. ${ }^{52}$ Appearance and outcome are all that count. The main achievement of liberal democracy lies in offering mechanisms for deposing Princes and selecting between their rivals for power that avoid the resort to violence. But in their campaigns to get elected, democratic Princes employ all the dark political arts - and in so doing prove their worthiness to rule. ${ }^{53}$ That does not mean that limits do not exist as to how foxy and leonine the Prince can be. But no public standards of cleanliness exist than those upheld by the public themselves. As Machiavelli notes, even for non-democratic Princes 'when it comes down to it only the masses count. ${ }^{54}$ In this respect, the virtue of liberal democracy rests less in its being imbued by liberal idealism and more in its institutionalising a degree of political realism that gives some rough equality through equal votes to how each member of the masses counts, and along the way the incentive of politicians to attempt to be cleaner than they ever can be.

\section{$\underline{\text { Conclusion }}$}

A study of the dirtiness of politics cannot end cleanly. There are no clean political decisions. Wolves and traps abound, not only because some people are wicked but also because most public issues are complicated and contested. They can only be resolved through force and persuasion. Thus, the role of a politician does not afford them the luxury of being good in a manner appropriate to many private roles. The good politician must do things even the good citizen would not. Likewise, a liberal idealism built on our duties as persons, beyond any role, proves a chimera. Nor can we clean up politics with a sui generis political morality based on distinctively public as opposed to private reasons. Our public reasons differ and not 
all can be accommodated, while wolves lurk and traps abound to ensnare the good politician as he or she attempts to uphold the common welfare. So politicians must act as foxes and keep certain things hidden. They must appear to be good, but know how not to be. Liberal idealism offers a clean glove of legitimacy, but not a clear guide to what is right and good. Unjust settlements can also gain a spurious justification when liberal norms of equality get applied to unequal circumstances. Yet, keeping some faith with liberal democratic ideals reminds politicians of the need to act proportionally and with popular support. Appearing to be good offers an incentive to attempting to be so. However, no public measure exists to mark where they overstep the line beyond their ability to convince the public they have succeeded. In a democracy, citizens share in the dirt of their politicians but - hypocritically perhaps - also offer the only means to keep it as clean as their good - the good of the public can ever allow it to be.

I'm grateful to my colleagues Cecile Laborde and especially Albert Weale for their very helpful comments on earlier versions. Stimulating discussions of the paper's ideas were also provided by Darrow Schecter and the participants of the Sussex Centre for Social and Political Thought seminar, David Miller and the members of the Nuffield Political Theory Workshop, and Bernard Reber, Kate Nash and Emmanuel Picavet among others at a 
presentation in the seminar series `Analyse des Normes Contemporaines' at CERSES, Université Paris Descartes.

${ }^{1}$ M Walzer (1972) 'Political Action: The Problem of Dirty Hands', Philosophy and Public Affairs 1: 162

2 A. Smith ([1776] 1981) An Inquiry Into the Nature and Causes of the Wealth of Nations, Indianapolis: Liberty Fund, Vol. I ed. R. H. Campbell and A. S. Skinner, Book I, chap. 2, para. 2

${ }^{3}$ See S. Hampshire, 'Public and Private Morality', in S. Hampshire (ed) (1978), Public and Private Morality, Cambridge: Cambridge University Press, p. 49 for a useful summary.

${ }^{4}$ See T. Nagel, Ruthlessness in Public Life', in Hampshire (ed), Public and Private Morality, pp. 75-91 for one such attempt, explored in section 1, and J. Rawls, Political Liberalism, New York: Columbia University Press, 1993, for another, explored in section 2.

${ }^{5}$ E.g. J Quong (2004) 'The Scope of Public Reason.' Political Studies, 52: 233-250

${ }^{6}$ E.g. J. Rawls (1993), Political Liberalism, New York: Columbia University Press, p. 214

${ }^{7}$ J. Waldron (1999) Law and Disagreement, Oxford: Oxford University Press, pp. 107-18;

A. Weale (1999), Democracy, Basingstoke: Macmillan, pp. 8-13.

${ }^{8}$ That certain dilemmas of democratic Princes stem from their obligations to the electorate is noted by both B. Williams, 'Politics and Moral Character' in Hampshire (ed), Public and Private Morality, pp. 60-70 and M Hollis (1982), 'Dirty Hands', British Journal of Political Science 12: 396-7, two classic essays that inspire more generally much of the present article. 
${ }^{9}$ A move in this direction appears to lie behind the nuanced case for a limited moral absolutism in T. Nagel, 'War and Massacre', reproduced in T. Nagel (1979) Moral Questions, Cambridge: Cambridge University Press, Ch. 5.

${ }^{10}$ E.g. Rawls, Political Liberalism, p. 161.

11 N. Machiavelli ([1513/32] 1995) The Prince, ed. and trans. D. Wootton, Indianapolis: Hackett and M. Weber ([1919] 1994), 'The Profession and Vocation of Politics' in Political Writings, ed. P. Lassman and D. Speirs, Cambridge: Cambridge University Press, pp. 309-69.

12 J. Elster (ed) (1998), Deliberative Democracy, Cambridge: Cambridge University Press, pp. $12,111$.

${ }^{13}$ I take this metaphor from Hollis's pithy summary of Machiavelli's views in The Prince as 'He should get his hands dirty and wear clean gloves' in Hollis (1982), 'Dirty Hands', p. 389.

${ }^{14}$ See , for example, the similarities and contrasts between Machiavelli, The Prince, pp. 48-9 and Hampshire, 'Public and Private Morality', pp. 49-50 and Nagel, 'Ruthlessness', pp. 8991.

${ }^{15}$ On the distinction between the `non-derivability' of public from private morality and their ‘independence' from each other, see Nagel, 'Ruthlessness', pp. 78-9, who notes (and appears to hold) that 'both may derive from a common source that yields different results when applied to the generation of principles for action in the widely differing circumstances of private and public life'. The argument of this section is that they are both non-derivable and independent from each other.

${ }^{16}$ Hollis, 'Dirty Hands': 390. 
${ }^{17}$ Hollis, 'Dirty Hands',: 393, S. Mendus (2010), Politics and Morality, Cambridge: Polity Press, pp. 33-34, 43.

18 Mendus, Politics and Morality, pp. 29-30. See too Weber, 'The Profession and Vocation of Politics', pp. 357-69.

19 Hollis, 'Dirty Hands': 390.

20 Nagel, 'War and Massacre', p. 63.

${ }^{21}$ Nagel, 'War and Massacre', pp. 64-73. Kant likewise allows for the 'moral politician ... who conceives of the principles of political expediency in such a way that they can co-exist with morality'. I. Kant (1970), 'On the Disagreement Between Morals and Politics in Relation to Perpetual Peace', in Kant's Political Writings, ed. H Reiss, Cambridge: Cambridge University Press, p. 118.

${ }^{22}$ Nagel in 'War and Massacre', which I take as an exemplary case of this sophisticated account, appears to base his reasoning on what in 'Ruthlessness' he refers to as the 'common source' of morality - namely, what we owe as moral individuals to other persons as such.

23 Walzer, 'Political Action': 168.

24 This is clearly the case in Kant, 'On the Disagreement Between Morals and Politics', p. 117.

${ }^{25}$ Hollis, 'Dirty Hands': 393-95.

${ }^{26}$ Rawls Political Liberalism, p. 223.

27 Rawls, Political Liberalism, p. 161.

${ }^{28}$ Rawls, Political Liberalism, p. 161. 
${ }^{29}$ Rawls, Political Liberalism, p. 157.

${ }^{30}$ Rawls, Political Liberalism, pp. 213, 223-27.

${ }^{31}$ Rawls, Political Liberalism, p. 214

32 Rawls, Political Liberalism, pp. 215-6, 231-40.

${ }^{33}$ Rawls, Political Liberalism, pp. 55-57

34 RJR MacDonald Inc. v Canada, [1995] 3 S. C. R. 199.

35 I have documented these issues in R. Bellamy (2007) Political Constitutionalism: A Republican Defence of the Constitutionality of Democracy, Cambridge: Cambridge University Press, especially Ch. 1.

36 See Bellamy, Political Constitutionalism, Ch. 2 and C. R. Sunstein (1996) Legal Reasoning and Political Conflict, Oxford: Oxford University Press, pp. 48-50.

${ }^{37}$ Rawls, Political Liberalism, p. 251.

${ }^{38}$ Quoted in Shuhei Kurizaki (2007) `Efficient Secrecy: Public Versus Private Threats in Crisis Diplomacy'. American Political Science Review,101: p. 543.

39 See C Brown and D McKittrick, 'The Secret IRA Meetings: IRA leak puts Major on rack', The Independent, 29/11/1993, accessed at http://www.independent.co.uk/news/the-secret-irameetings-ira-leak-puts-major-on-rack-mi6-blamed-for-unauthorised-contacts--mayhew-topublish-more-documents-1507407.html

40 Machiavelli, The Prince, p. 48. 
${ }^{41}$ Machiavelli, The Prince, p. 48.

${ }^{42}$ Machiavelli, The Prince, p. 49.

${ }^{43}$ Machiavelli, The Prince, p. 54.

${ }^{44}$ For proportionality as a restraint in both Machiavelli and Weber see M. Philp (2007),

Political Conduct: Cambridge MA: Harvard University Press, Ch. 4.

45 Weber, 'The Profession and Vocation of Politics', pp. 310-11.

${ }^{46}$ Machiavelli, The Prince, p. 30

47 Machiavelli, The Prince, p. 67

${ }^{48}$ N. Machiavelli ([1513-17] 1960) Discorsi sopra la prima deca di Tito Livio in Il Principe e Discorsi ed S Bertelli, Milan: Feltrinelli, Bk 1 Ch IX, p. 153

${ }^{49}$ Machiavelli, The Prince, pp. 30-31.

${ }^{50}$ I discuss the different types of compromise and their relationship to the circumstances and groups involved in R. Bellamy (1999), Liberalism and Pluralism: Towards a Politics of Compromise, London: Routledge, especially Ch. 4.

51 Michael Freeden (2005) 'What Should the "Political” in Political Theory Explore?', Journal of Political Philosophy, 13: 123.

52 Machiavelli, The Prince, pp. 54-55.

${ }^{53}$ Once again the classic account of this key feature of modern politics, whereby the Prince became a Democratic Prince, is Weber, 'The Profession and Vocation of Politics'.

${ }^{54}$ Machiavelli, The Prince, p. 55. 